\title{
PAULO FREIRE E A CONDIÇÃO DA MULHER
}

\author{
PAULO FREIRE AND WOMAN CONDITION
}

PAULO FREIRE Y LA CONDICIÓN DE LA MUJER

\begin{abstract}
Balduino Antonio Andreola*
Professor do Programa de Pós-Graduação em Educação do Centro Universitário La Salle de Canoas
\end{abstract}

Resumo: De natureza bibliográfica, neste ensaio teve-se por objetivo (re)visitar o tema da condição da mulher na obra de Freire. $\mathrm{O}$ autor denuncia toda forma de discriminação. A da mulher, mais explicitamente em Pedagogia da Esperança, À sombra desta mangueira, Pedagogia da Indignação e Pedagogia dos sonhos possíveis. Sobre Pedagogia do Oprimido declarou que jamais teria escrito o livro se permitisse oprimir suas filhas, sua mulher ou as mulheres com quem trabalhava. Mas aceitou as críticas das feministas americanas de que a linguagem daquele livro era machista. Por outro lado, um amplo movimento feminista na Suíça se inspirou naquela obra para sua luta, sem vê-la na mesma linguagem machista. Segundo o grande linguista Manfred Peters, a mudança da linguagem machista deve inserir-se num processo de transformação social, sem o qual somente alterações da linguagem não resolvem o problema.

Palavras-chave: Mulheres. Machismo. Feminismo. Freire. Discriminação.

Abstract: This article of bibliographical nature has as objective to (re)visit the issue of the woman condition in Freire's work. Hes denounces all forms of discrimination. The one of the woman, more explicitly in Pedagogy of Hope, In the shadow of this hose, Pedagogy of Indignation and Pedagogy of possible dreams. About Pedagogy of the Oppressed, he has stated that he would never have written the book if it permitted to oppress his daughters, his wife or the women with whom he worked. But he accepted the criticisms of American feminists that the language of that book was chauvinist. On the other hand, a broad feminist movement in Switzerland was inspired on that

\footnotetext{
* Doutor em Ciências da Educação pela Université Catholique de Louvain - Belgica; Pós-doutorando em Educação pela Universidade Federal do Rio Grande do Sul.
} 
work for its struggle, without seeing the same chauvinist language. According to the great linguist Manfred Peters, the change of the chauvinist language should insert itself into a process of social transformation, without which no language changes would solve the problem.

Keywords: Women. Chauvinism. Feminism. Freire. Discrimination.

Resumen: De naturaleza bibliográfica, el ensayo tiene como objetivo (re)visitar el tema de la condición de la mujer en la obra de Freire. El autor denuncia toda forma de discriminación. La de la mujer, más explícitamente en Pedagogía de la Esperanza, A la sombra de esta manguera, Pedagogía de la Indignación y Pedagogía de los sueños posibles. Sobre Pedagogía del Oprimido, declaró que jamás habría escrito el libro si permitiese oprimir a sus hijas, a su mujer o a las mujeres con las que trabajaba. Pero aceptó las críticas de las feministas estadounidenses de que el lenguaje de aquel libro sería machista. Por otro lado, un amplio movimiento feminista en Suiza se inspiró en aquella obra para su lucha, sin ver en ella lenguaje machista. Según el gran lingüista Manfred Peters, el cambio del lenguaje machista se debe inserirse en un proceso de transformación social, sin el cual tan sólo alteraciones del lenguaje no resolverian el problema.

Palabras clave: Mujeres. Machismo. Feminismo. Freire. Discriminación.

\section{INTRODUÇÃO}

"Desrespeitando os fracos, enganando os incautos, ofendendo a vida, explorando os outros, discriminando o índio, o negro, a mulher não estarei ajudando meus filhos a ser sérios, justos e amorosos da vida e dos outros..."

(Paulo Freire, 1997, p. 11)

As palavras da epígrafe são as últimas que Paulo Freire deixou escritas na sua Terceira Carta Pedagógica, que nos deixou inconclusa em cima de sua mesa, poucos meses antes de morrer. Naquela mesma "Carta", alguns parágrafos antes, havia escrito: “[...] não creio na amorosidade entre mulheres e homens, entre os seres humanos, se não nos tornarmos capazes de amar o mundo."

Em uma de suas vindas a Porto Alegre, em 1988, convidado para uma fala aos docentes da UFRGS no auditório da farmácia, Freire iniciou assim: "Minhas prezadas professoras!" Fez uma pausa de alguns segundos e continuou: "Por que deveria eu iniciar dizendo: meus prezados professores, se a grande maioria, nesta sala, são professoras?" 
No livro Pedagogia da Esperança, Freire menciona que usou em outras oportunidades esse recurso gramático-pedagógico no intuito de chamar a atenção do público para o machismo da linguagem, denunciado nos questionamentos levantados pelo movimento feminista dos Estados Unidos após a tradução de Pedagogia do Oprimido ao inglês, em fins de 1970 e início de 1971. Ele escreveu que ao retomar Pedagogia do Oprimido passou a reconhecer a "marca machista" com que escrevera aquele livro e Educação como prática da liberdade. Ao revisar sua linguagem machista, o fazia como "[...] dívida a um sem número de mulheres norte-americanas, que, de diferentes partes dos Estados Unidos" (FREIRE, 1992, p. 67) lhe escreviam. Elas diziam que, ao discutir a opressão e denunciando as estruturas opressoras, ele usava uma linguagem machista. Elas exemplificavam com diferentes citações do livro, como esta, por exemplo: "Desta forma, aprofundando a tomada de consciência da situação, os homens se 'apropriam' dela como realidade histórica, por isso mesmo, capaz de ser transformada por eles.” (FREIRE, 1992, p. 66-67).

Freire acrescenta que elas perguntavam: Por que não, também, as mulheres? Continuando a reflexão sobre o tal "machismo" da linguagem, confessa que depois das primeiras cartas reagiu, condicionado pela ideologia autoritária, machista, tentando justificar a si mesmo, dizendo: "Quando falo homem, a mulher está incluída." Aos poucos, porém, foi-se dando conta da "mentira ideológica" daquela sua justificativa. Ele pergunta, então: "E por que os homens não se acham incluídos quando dizemos: ‘As mulheres estão decididas a mudar o mundo'?” (FREIRE, 1992, p. 67). Embora no início reagisse justificando-se, passou a levar muito a sério o débito àquelas mulheres, e declarou: "Escrevi, então, a todas, uma a uma, acusando suas cartas e agradecendo a excelente ajuda que me haviam dado." (FREIRE, 1992, p. 67).

Em muitas oportunidades, falando ou escrevendo, Freire se dirigia a seus ouvintes ou a suas leitoras e seus leitores, explicitando os dois gêneros. No livro já citado, Pedagogia da Esperança, ele relata que passou a adotar esse recurso gramático-pedagógico no intuito de chamar a atenção do público para o machismo da linguagem. Ele assumiu essa espécie de "subversão" da gramática usual, marcada por um "masculinismo" plurimilenar, a partir do questionamento das feministas norte-americanas.

O uso desse recurso gramatical não significa que Freire tivesse reconhecido uma intencionalidade machista em seus escritos, como cobram dele algumas estudiosas ou alguns estudiosos de sua obra. Pelo contrário, ele já havia dado uma resposta relatada por Moema L. Viezzer que escreveu, para o livro Paulo Freire: Uma Biobibliografia (GADOTTI, 1996), o texto intitulado Paulo Freire e as relações sociais de 
gênero. Ela contou que num encontro nacional sobre Educação Popular, em Piracicaba, em 1986, fez por escrito a seguinte pergunta: "Paulo, como você vê a questão das relações de dominação e opressão entre homens e mulheres em nossa sociedade?" (VIEZZER. 1996, p. 596). A autora da pergunta comentou que esta causou visível enervamento entre várias pessoas da plateia. A resposta foi esta:

Eu jamais teria escrito Pedagogia do Oprimido se, ao mesmo tempo, eu me permitisse oprimir minhas filhas, minha esposa e as mulheres com quem trabalho. As mulheres estão certas em organizar-se e dizer o que tem que ser mudado em relação às opressões que hoje sofrem. E nós, educadores, precisamos entendê-las, ouvi-las e acompanhar as mudanças que ocorrerão graças às suas iniciativas.

O episódio de Porto Alegre, citado no início, serviu para salientar a maneira como Freire reagia ao uso de uma gramática no masculino, para explicitar como tratou e trataria todas as mulheres ao longo de toda a sua vida. O episódio relatado por Moema L. Viezzer e a resposta de Freire contêm um princípio hermenêutico válido para a interpretação da obra de qualquer autora ou autor. Usando esse argumento num trabalho sobre "Paulo Freire e a Ecologia", antes de realizar aquele que denominei "um vôo panorâmico sobre várias obras de Freire", parti da sua obra principal, Pedagogia do Oprimido, na qual não lemos nenhum texto que fale diretamente do problema ecológico. Sendo, porém, a opressão o tema central do livro, pergunto-me se o arrasar a casa de alguém não é uma das modalidades mais cruéis de opressão. Ou, pior ainda, mandar que avancem com o trator por cima das casas pobres de uma população de vila periférica, como fazem certos prefeitos, porque aí tem que se instalar uma multinacional. Continuando meu raciocínio, perguntei-me, então, e pergunto agora, se não significa opressão infinitamente mais cruel, em se tratando da destruição da casa comum da humanidade, o planeta Terra, a ameaça de destruir todas as formas de vida que habitam esta casa de todos nós.

Paulo Freire, para responder à pergunta de Moema, esclarece que se ele se permitisse oprimir sua esposa, suas filhas e as mulheres com as quais trabalhava, jamais teria escrito Pedagogia do Oprimido. A mesma resposta Freire deu a alguns marxistas "ortodoxos", que o cobravam não ter explicitado, em seu livro Pedagogia do Oprimido, a luta de classes. Ele respondeu que achava evidente a referência à luta de classes na contraposição dialética opressor-oprimido. Disse, porém, e escreveu em várias oportunidades, que a partir daquela acusação explicitava essa ideia até ao escrever cartas. Mas tem mais. Em uma entrevista com Donaldo Macedo, em 1998, Freire 
abordou simultaneamente a crítica das feministas norte-americanas e a dos marxistas “ortodoxos", declarando:

\begin{abstract}
Vamos agora nos voltar para a questão central do sexismo. Durante os anos 70, quando comecei a aprender com as feministas, principalmente com as feministas norte-americanas, devo dizer que eu era, naquela época, mais influenciado pela análise marxista, particularmente pela análise de classe. Quando escrevi Pedagogia do Oprimido, estava muito influenciado pela análise de classe de Marx e, dada a cruel opressão de classe que caracterizou meus anos de desenvolvimento no Nordeste do Brasil, minha maior preocupação era, portanto, a opressão de classe. É irônico o fato de alguns marxistas terem me criticado por não ter prestado atenção suficiente à análise de classe social. Em Pedagogia do Oprimido, se minha memória não falha, fiz aproximadamente 33 referências à análise de classe social (FREIRE, 2001, p. 261, grifo nosso).
\end{abstract}

O significado de uma obra não é engessado como em letra morta. As hermenêuticas de diferentes leituras desdobram, com certeza, os sentidos e os significados que a obra contém, ora enriquecendo e ampliando seu significado, ora restringindo-o e até deturpando-o. Numa conversa informal com Paul Ricoeur, em 1983, no meu estágio de um mês na biblioteca Mounier, em Châtenay-Malabry, ele me deu, sem perceber, uma aula breve mas inesquecível de hermenêutica. Referindo-se à morte de Mounier, acontecida em 1950, ele disse: "Era uma grande amizade que estava se estabelecendo entre nós. Mas eu lecionava em Strasburgo, e só nos encontrávamos por ocasião dos seminários da revista Esprit, em Paris. O lado mais cruel da morte é que a gente faz perguntas ao amigo, e ele não responde mais."

Eu lembrei, naquele instante, que ele estava repetindo, com a mesma emoção, o que havia escrito 30 anos antes, no artigo de um número especial da revista Esprit, publicada em homenagem póstuma a Mounier. Naquela ocasião desdobrou assim seu pensamento: "Para escrever este artigo, eu leio seus escritos, e tento continuar o diálogo, agora impossível." E acrescentou: “Um autor é um homem virtualmente morto.” (RICOEUR, 1955, p. 135).

Voltando à "questão da mulher" em Freire, na linha de uma leitura hermenêutica e não de uma leitura material do texto por nós engessado, cabe a nós, leitoras e leitores, desdobrar e explicitar sentidos e significados não explicitados, possivelmente, pela autora ou pelo autor, que escreveu em momentos e contextos diferentes dos atuais. Desafiado pela pergunta de Moema, em lugar de respondê-la numa argumentação literalmente atual de seu pensamento, ele preferiu explicitar uma resposta que estaria evidente no seu livro Pedagogia do Oprimido, em coerência total com seu 
modo de tratar as mulheres da sua convivência, na família e no campo profissional. E há um segredo cruel de sua vivência de menino pobre e com fome que ele não explicitou em Pedagogia de Oprimido nem naquela entrevista, mas o fez em Cartas a Cristina. Ao falar da experiência cruel da fome, à qual foi levada sua família, com a crise provocada pela quebra, em 1929, da bolsa de Nova York, e da tristeza do pai, sentindo-se impotente para dar à família uma condição menos penosa, comenta: “[...] valeu muito mais para mim surpreender, aflito, meu pai em seu quarto, escondido dos filhos e da filha, chorando, sentado à cama, ao lado de sua mulher, nossa mãe, pela impotência diante dos obstáculos a vencer para dar um mínimo de conforto a sua família." (FREIRE, 1994, p. 62).

Depois de falar do pai, Freire confia ao papel suas memórias tristes, relacionadas com as humilhações sofridas pela mãe:

Quando, por exemplo, minha mãe, dócil e timidamente, pedindo desculpas ao açougueiro por não haver pago a ínfima quantidade de carne comprada na semana anterior, ao solicitar mais crédito para trezentos gramas a mais, prometia que pagaria as duas dívidas, na verdade ela não mentia nem tentava um golpe. Ela precisava acreditar em que realmente pagaria. E precisava, de um lado, por uma razão muito concreta - a fome real da família; de outro, por uma questão ética - a ética de mulher de classe média cristã católica. E quando o açougueiro, zombeteiro, machista, a desrespeitava com seu discurso de mofa, suas palavras a pisoteavam, a destroçavam, a emudeciam. Tímida e esmagada, eu a vejo agora, neste momento mesmo, eu a vejo frágil, olhos marejando, deixando aquele açougue à procura de outro em que quase sempre se acrescentavam outras ofensas às já recebidas. [...] Não estou hoje como até mesmo à época não estava pretendendo que o açougueiro às suas custas financiasse a nossa crise. Não era e não é isso. O que me revoltava era o desrespeito de quem se achava em posição de poder a quem não o tinha. Era o tom humilhante, ofensivo, canalha, com que o açougueiro falava a minha mãe. A entonação da censura, de reprovação do discurso do açougueiro, que ele prolongava desnecessariamente e de forma que todos, no açougue, ouviam, me fazia um tal mal que, agora, preciso me esforçar para descrever a experiência. (FREIRE, 1994, p. 63-64).

Depois de confiar, penosamente, ao papel aquela lembrança cruel de sua infância, Freire expressa com veemência a postura antimachista que ele terá ao longo de toda a sua vida:

Nesta altura, porém, não posso deixar de fazer um comentário sobre a cultura machista que nos marca. Só ela pode explicar, de um lado, que minha mãe tomasse para si sempre o incômodo enfrentamento dos credores; de outro, que meu pai, tão justo e correto, aceitasse sabê-la expondo-se como se expunha (mesmo 
que ela não o informasse do que ouvia nos açougues e bodegas) e não assumisse a responsabilidade de tratar com os credores. Era como se a autoridade do homem devesse ficar defendida, no fundo, falsamente defendida, resguardada, enquanto a mulher se entregava às ofensas. (FREIRE, 1994, p. 64).

Nessa ótica de luta contra todas as formas de machismo da cultura brasileira, a Professora Ana Maria, esposa de Freire, relata-nos uma "confissão" exemplar dele, como lemos no livro Nita e Paulo: crônicas de amor. Referindo-se a duas situações que “[...] doíam muito em Paulo", ela escreve:

Primeiro, lamentava a "proibição implícita" que os filhos impuseram à mãe de se casar de novo. Viúva aos 42 anos, não voltou a se casar. Entre uma nova chance de ser feliz, ou satisfazer a vontade dos filhos, optou pela segunda alternativa. "Fui egoísta, adolescente machista que não incentivou a mãe para um novo amor. Hoje, vejo como errei: é uma tirania dos filhos querer os pais só para si sem se importar com a opção de vida deles [...] Tantas vezes não respeitam suas decisões legítimas por uma nova vida amorosa e sexual", repetia sempre. (FREIRE, 1998, p. 34).

Em outra perspectiva de valorização da mulher, desta vez no campo profissional, cabe citar o livro Professora sim, tia não: cartas a quem gosta de ensinar (FREIRE, 1995). Paulo Freire, em várias oportunidades, retomou ideias centrais do livro, chamando a atenção para a ideologia que pode estar presente nessa linguagem amorosa, de tratar a professora por um título parental ou familiar, chamando-a de tia. Rosa Maria Torres relata um diálogo com professoras que nem sabiam do livro e que até estranharam que ela perguntasse que opinião tinham acerca de tia. Ela refere também que numa entrevista, Freire observa que quando chamam a professora de tia, está implícito neste tratamento que: “[...] a tia não pode fazer greve. Quanto mais se reduz a profissionalização a uma amorosidade parental, tanto menos são as condições que terá a professora para lutar.” (TORRES, 1996, p. 275).

Ao mesmo tempo em que estamos realizando este voo panorâmico sobre as obras de Freire, buscando suas verbalizações explícitas em torno das questões de gênero, acho necessário estarmos atentos a critérios de caráter mais hermenêutico, pois creio que não sirvam a ninguém determinadas análises descontextualizadas das obras de Freire ou de qualquer outro autor, cobrando o que ele não disse ou não escreveu.

No livro Pedagogia da Esperança, Freire dedica três páginas (66 a 68) a uma reflexão em torno da necessidade de superar a linguagem machista, e reconhece que esta sua preocupação se deve, em grande parte, àquelas numerosas mulheres que lhe escreveram, na década de 1970, após a publicação de Pedagogia do Oprimido 
em inglês. Ele é peremptório quanto à exigência de mudança da linguagem machista, declarando:

\begin{abstract}
Não se diga que, sendo o fundamental a mudança do mundo malvado, sua recriação, no sentido de fazê-lo menos perverso, a discussão em torno da superação da fala machista é de menor importância, sobretudo porque a mulher não é classe social. A discriminação da mulher, expressada e feita pelo discurso machista e encarnada em práticas concretas, é uma forma colonial de tratá-la, incompatível, portanto, com qualquer posição progressista, de mulher ou de homem, pouco importa. (FREIRE, 1992, p. 68).
\end{abstract}

No verbete "Mudança/Transformação Social", no dicionário Paulo Freire, Cênio Weyh mostra, a partir das obras de Freire, que ele é um educador comprometido com a transformação social, e esclarece: "Em Paulo Freire, mudança e transformação social assumem um caráter de comprometimento e engajamento nas lutas a favor das causas dos oprimidos" (WEIH, 2010, p. 276).

As cobranças das feministas americanas foram recebidas, inicialmente, com irritação por Freire e assumidas depois como participação na luta a favor da emancipação da mulher. Mas àquelas feministas caberia também devolver a cobrança. Aquele movimento se restringia somente à luta contra a opressão da mulher ou abraçaria também o combate contra o racismo, a guerra do Vietnã, e a dominação capitalista sobre os países centro e sul-americanos? Além disso, o problema da linguagem "masculinista", como no caso de falar ou escrever "homem", entendendo abranger homens e mulheres, é um problema plurissecular ou até plurimilenar.

Ao analisar uma obra, não importa de que autor ou autora, não podemos dissociá-la das condições existenciais e históricas em que foi escrita. Quanto às existenciais, já escrevi que a experiência da pobreza e da fome em Jaboatão significou também a "arqueologia" sociopolítica da Pedagogia do Oprimido, quando o menino Paulo se propôs uma pergunta do tamanho do mundo, como lemos no livro Conscientização (FREIRE, 1979, p. 14): “Em Jaboatão, quando tinha dez anos, comecei a pensar que no mundo muitas coisas não andavam bem. Embora fosse criança comecei a perguntar-me o que poderia fazer para ajudar aos homens."

Na mesma linha de raciocínio, podemos pensar que aquela experiência triste e cruel de presenciar a mãe sendo alvo de desprezo e injúria grosseira por parte do açougueiro o imunizou para o resto da vida de qualquer gesto ou palavra de menosprezo ou desrespeito para com uma mulher, pois valorizava ao extremo as mulheres que com ele conviveram ou trabalharam. O exemplo mais eloquente de valorização foi o de seu relacionamento com sua primeira esposa Elza, falecida em 1986, e com 
sua segunda esposa Ana Maria. Quanto à Elza, professora e diretora de escola, são inúmeras as referências em seus livros, tanto que ele disse um dia, a um de seus filhos, que com certa frequência lhe escreviam, ou então lhe diziam, ao encontrarem-se com ele, que estavam gostando de seus livros. Ele comentou que algumas pessoas o diziam com sinceridade, porque de fato leram, mas que outras o faziam para agradá-lo. E acrescentou jocosamente: "Daqui por diante, vou perguntar: "Qual é o nome de minha esposa?" Se não souberem, é porque não leram, sendo que eu falo dela praticamente em todos os meus livros."

Quanto à segunda esposa, Ana Maria Araujo Freire, considerando que ela é doutora em História da Educação, valorizou-a também por esta sua competência, pedindo-lhe que redigisse, em anexo, as notas para três de seus livros: Pedagogia da Esperança, Cartas a Cristina e À sombra desta mangueira. De Ana Maria Freire temos também numerosos outros escritos relacionados com a obra e a biografia de Paulo Freire, em particular a apresentação dos vários livros póstumos, além de seus numerosos depoimentos no livro de sua autoria Nita e Paulo: Crônicas de amor (FREIRE, 1998).

Elza era uma mulher muito discreta em suas falas. Mas, sob esta atitude humilde de discrição, ela ocultava uma sabedoria profunda, que Freire explicita quando, ao citá-la, salienta que a fala da esposa tem, naquelas ocasiões, uma importância enorme. Evocarei dois exemplos apenas, um do livro Medo e Ousadia e o outro de Cartas à Guiné-Bissau. Em Medo e Ousadia, no diálogo com Ira Shor, ele declara:

A primeira vez que vim aos EUA, vim por causa de Elza, minha mulher. Quando fui convidado, disse a Elza que não viria, porque eu não teria nada a aprender num país tão imperialista. Ela me disse sorrindo: "Como você é contraditório e ingênuo. É impossível pensar que este país seja apenas imperialista. É impossível que seja só isso. Você tem muitas coisas para aprender lá". Imediatamente ela me convenceu, e vim aos EUA. Desde então, nunca parei de vir. Venho todos os anos, e sempre aprendo alguma coisa - ainda que seja apenas como é difícil aprender sobre esta cultura. (FREIRE, 2000, p. 14).

No livro Cartas à Guiné-Bissau, destacarei outra fala breve, mas inesquecível, de Elza, no contexto de uma grande festa popular. Freire (1978, p. 38-39) escreveu:

Já em Bissau, enquanto nos preparávamos, em equipe, para a última fase de nossa visita, houve um fato que nos marcou profundamente e que tem a ver com muitas das considerações feitas nesta introdução. Sobre ele, desde então, tenho falado sempre em seminários e não gostaria, agora, de silenciá-lo. 
Manhã quente de setembro. Asfixiante, quase. Comemorava-se a independência do país. [...] A multidão cantava também, movia-se também. Não se tratava de um "espetáculo folclórico" a que uns poucos, à distância, assistissem. Era uma festa do povo, que vivia o seu dia maior. Após o desfile, encerrado com a apresentação de unidades das FARP, o Presidente Luiz Cabral começou então o seu discurso. Exatamente em frente ao local do palanque em que se achava o Presidente, um grupo da banda militar, perfilado. Em certo momento, um dos soldados da banda, como se estivesse caindo sobre si mesmo, desfalece. O Presidente pára o seu discurso. Olha fixo o militante que está sendo amparado por seus camaradas. A multidão percebe. Abre caminho a um carro que se aproxima e em que o soldado é conduzido ao hospital. O Presidente acompanha com o olhar o carro que parte e logo desaparece. Só então volta a falar. Ao meu lado, em voz baixa, diz Elza: "Este foi o momento mais bonito de nossa visita a este país. Temos realmente muito o que aprender de um povo que vive tão intensamente a unidade entre a palavra e o gesto. O indivíduo aqui vale enquanto gente. A pessoa humana é algo concreto e não uma abstração.

Segundo Silva (2010, p. 183), em seu verbete "Feminismo", no Dicionário Paulo Freire, foi na obra Medo e Ousadia, escrita em co-autoria com o professor americano Ira Shor, que “[...] Freire deixa nítido seu engajamento na luta contra o patriarcado. E é aí que aparece mais nitidamente o reconhecimento pela luta das mulheres."

Cabe reconhecer o mérito de Márcia Alves da Silva ao salientar a maneira como Freire trata da condição da mulher em Medo e Ousadia. Mas ela inicia seu verbete escrevendo: "Inicialmente, podemos afirmar que Paulo Freire pouco dialogou com o movimento feminista." (SILVA, 2010). E a cobrança do que ela considera omissão perpassa todo o texto. Neste sentido, caberia a ela e a outros cobradores ou cobradoras a cobrança de uma omissão bibliográfica grave. O Dicionário Paulo Freire, em segunda edição ampliada, foi publicado em 2010. Mas já em 2001 havia sido publicado Pedagogia dos Sonhos Possíveis, um dos livros póstumos de Freire, da série Paulo Freire, organizada por sua esposa Ana Maria Araujo Freire (FREIRE, 2001). E é nesse livro que Freire explicita mais exaustivamente suas posições sobre a condição da mulher e em torno dos questionamentos das feministas norte-americanas. Ele o faz num diálogo muito exigente com seu parceiro de outras horas e coautor de um livro, Donaldo Macedo (FREIRE, 2001). O mesmo texto já fora publicado em 1998 (FREIRE apud MCLAREN, 1998).

Aquela entrevista com Donaldo Macedo saiu significativamente com o título: Opressão, classe e gênero. A relação com o livro clássico de Paulo Freire é evidente, aparecendo de maneira mais explícita já na primeira pergunta do entrevistador: 


\begin{abstract}
Alguns/algumas educadores/educadoras, particularmente as feministas norte-americanas, argumentam que seu trabalho tende a universalizar a opressão enquanto ignora as especificidades de posições diversas e contraditórias que caracterizam os grupos subordinados juntamente às linhas de cultura, etnia, linguagem, raça e gênero [...] (FREIRE, 2001, p. 257).
\end{abstract}

A pergunta de Donaldo é longa, explicitando todas as nuances das críticas e cobranças feministas. A crítica mais insistente é a de Freire universalizar a opressão esquecendo ou omitindo as especificidades e sua falha em apreciar diferentes localizações históricas de opressão.

Se o questionamento com que Macedo tentou resumir todas as críticas feministas dos EUA foi extenso, nas respostas Freire também se delongou, ponderando que os questionamentos das feministas norte-americanas se relacionavam com a questão de gênero em Pedagogia do Oprimido. Ele considera aquela crítica “[...] não apenas válida, mas muito acurada.” (FREIRE, 2001, p. 259). A certa altura, em suas ponderações, ele declara: "É com grande satisfação que eu admito que meu engajamento com movimentos feministas possibilitaram-me tomar um foco mais apurado das questões de gênero.” (FREIRE, 2001, p. 260).

Todas as críticas e todas as respostas de Freire referem-se ao livro Pedagogia do Oprimido, mais especificamente, à sua linguagem sexista, segundo as feministas. As respostas de Freire são ponderadas, cavalheirescas, numa linha positiva. Mas a certa altura ele muda de tom e escreve:

De fato recebi, há pouco tempo uma carta de uma jovem mulher
que recentemente leu, pela primeira vez, Pedagogia do Oprimi-
do, criticando minha linguagem machista. Essa carta foi mui-
to insultante e até um pouco vulgar. Não estava chateado pela
carta que ela escreveu porque, certamente, ela leu Pedagogia
do Oprimido para avaliar minha linguagem, como se o livro
tivesse sido escrito no ano passado; isto é, ela não contextuali-
zou Pedagogia do Oprimido em seu contexto histórico; mas não
me interprete mal: não estou me desculpando pela linguagem
sexista desse livro. Estou apenas esclarecendo que, durante
meus anos de formação não escapei dos poderes envolventes de
uma cultura altamente sexista no meu país. No entanto, desde a
publicação de Pedagogia do Oprimido, tenho tentado remover
de minha linguagem todas essas características que são degra-
dantes para as mulheres. Se essa mulher jovem pudesse ler, por
exemplo, A politica da educação que você, Donaldo, traduziu
- você lembra minha insistência sobre evitar linguagem sexista
- e Alfabetização: leitura do mundo, leitura da palavra, do qual
nós fomos co-autores, ela veria a diferença marcante na lingua-
gem utilizada. (FREIRE, 2001, p. 261, grifo nosso). 
Freire volta à questão central do sexismo e repete que aprendeu muito com as feministas americanas. Observa que quando escreveu Pedagogia do Oprimido ele era mais influenciado pela análise marxista, particularmente pela análise de classe, como lembrado no início deste ensaio. Ao falar em transformação, ele considerava óbvio que "[...] a libertação deveria ter lugar para homens e mulheres não apenas para homens ou para mulheres ou para as pessoas negras e de linhas étnicas." (FREIRE, 2001, p. 262).

Macedo retoma, a certa altura da entrevista, a crítica das feministas de que Freire "[...] universaliza a opressão sem levar em conta a multiplicidade de experiências opressivas que caracterizam as histórias vividas pelos indivíduos juntamente com raça, gênero, etnia e linhas religiosas." (FREIRE, 2001, p. 262). Freire volta, e desta vez mais explicitamente, a uma questão já abordada, declarando:

Sem evitar a questão de gênero, devo dizer que os leitores/as leitoras têm alguma responsabilidade em colocar meu trabalho inserido nesse contexto histórico e cultural; isto é, a pessoa lendo Pedagogia do Oprimido como se tivesse sido escrito ontem, de alguma forma descarta a historicidade do livro. O que eu acho absurdo é ler um livro como Pedagogia do Oprimido e criticá-lo porque o autor não tratou de todos os temas de opressão potencial de forma igualitária. Acredito que o que uma pessoa precisa fazer é apreciar a contribuição do trabalho inserido em seu contexto histórico. (FREIRE, 2001, p. 262-263).

Ao longo de toda a entrevista, e mesmo em outras obras que abordam as questões de gênero em Paulo Freire, tudo parece girar em torno de Pedagogia do Oprimido e das críticas das feministas americanas. Mesmo a crítica daquela leitora que lhe escreveu numa linguagem, segundo ele, "um pouco vulgar", foi anterior à data de publicação dessa entrevista, ou seja, em 1997 ou 1998, quando Freire havia voltado há uns 15 anos do Conselho Mundial de Igreja (CMI), no qual permanecera dez anos. A partir de Genebra, com todo o respaldo do CMI, realizou aproximadamente 150 viagens internacionais, para países de todos os continentes, conforme o dossiê dos seus cronogramas, trazidos anexos à tese de doutorado de Mário Bueno Ribeiro (2002). Além disso, haviam passado quase 30 anos desde as primeiras edições de $P e-$ dagogia do Oprimido em espanhol (1970), inglês (1970) e francês (1971); no Brasil foi editado, com o corte de uma página. Em 1974 muita coisa havia mudado, portanto, tornando questionáveis as críticas que se fixaram na análise da linguagem considerada sexista daquele livro.

No livro Medo e Ousadia: O cotidiano do professor, que é um diálogo entre Paulo Freire e o professor norte-americano Ira Shor, são dedicadas várias páginas 
à questão da mulher (FREIRE; SHOR, 2000, p. 195-201). A conversa parte de um relato que Shor faz da sua experiência em sala de aula. Depois de dialogar com Freire sobre a conveniência ou não do humor em sala de aula, Ira Shor levanta o que denomina “[...] dois aspectos específicos de linguagem." O primeiro é que em suas aulas: "[...] os homens interrompem as mulheres, não deixam que elas terminem sua fala. Algumas insistem no seu direito de terminar, mas a maioria está acostumada a ceder." (FREIRE; SHOR, 2000, p. 195).

Shor refere que quando isso acontece, ele interrompe o homem e diz que a colega tem direito de terminar. O segundo aspecto referido por ele é que as alunas, em suas aulas, tendem a falar em voz mais baixa que os homens. Pondera também que as mulheres têm menos oportunidade de se manifestarem criticamente em público, e que ele procura compensar, pedindo que elas estendam seus comentários quando falam. Shor conclui perguntando a Freire se no Brasil são problemas em sala de aula o sexismo e o racismo.

Freire responde: "São, sim. A sociedade brasileira é muito autoritária.” E acrescenta que tanto o racismo quanto o machismo são fortes no Brasil. Por outro lado, observa que ao voltar ao Brasil encontrou, como uma das novidades, "[...] a luta das mulheres [...] que começaram a lutar, começaram a protestar, começaram a rejeitar o fato de continuarem a ser objetos dominados pelo homem.” (FREIRE, 2000, p. 197).

Quanto ao comportamento das mulheres em sala de aula e mesmo em discussões com até 3.000 estudantes, Freire disse que não viu o tipo de coisa que Shor observara em suas aulas, apesar de nossa cultura machista. Ponderou que não cabe aos homens libertar as mulheres, porque a libertação deve ser conquista delas. Mas cabe aos homens contribuírem na luta delas, “[...] que também é nossa, isto é, daqueles homens que não aceitam a posição machista do mundo." (FREIRE, 2000, p. 198).

Parece-me interessante observar que Shor fala em sexismo o que Freire denomina, quase o tempo todo, machismo. A uma pergunta de Shor de como tratar dos "discursos entre sexos e raças" em sala de aula, Freire respondeu numa perspectiva de transformação social:

Isso depende, Ira. Em primeiro lugar, vejo o racismo e o sexismo muito ligados à produção capitalista. Não digo que devam ser reduzidos só à questão do capitalismo. Não digo que o racismo e o sexismo possam ser reduzidos à luta de classes. Mas, o que quero dizer é que não acredito na possibilidade de superar o racismo e o sexismo num modo de produção capitalista, numa sociedade burguesa. Não obstante, isso não significa que o racismo e o sexismo serão superados mecanicamente numa sociedade socialista. Para mim, esta é uma das tarefas a ser cumprida pelos revolucionários. Se realmente queremos reinventar a so- 
ciedade, para que as pessoas sejam cada vez mais livres e mais criativas, esta nova sociedade deve ser criada por homens e por mulheres. (FREIRE; SHOR, 2000, p. 199).

Aqui me parece oportuna a citação de um dos maiores estudiosos de Freire no campo da linguística, o belga Manfred Peters. Ele escreveu, inclusive, um texto intitulado Prolegômenos a uma gramática dos oprimidos, e participou do livro $\mathrm{Pe}$ dagogia da libertação em Paulo Freire (PETERS, 1999, p. 157-162) com um texto intitulado Aspectos semânticos e pragmáticos da pedagogia de Paulo Freire. As ideias discutidas no texto, segundo o autor, “[...] não são de natureza puramente acadêmica, tendo suas raízes em dois projetos concretos" [...], um realizado na "Universidade da Paz" de Namur, na Bélgica, e o outro, inserido num "[...] programa de desenvolvimento da União Européia, chamado Alfabetização e Conscientização no Kivu, da República Democrática do Congo.” (PETERS, 1999, p. 157-162).

Feitos esses breves acenos a vários estudos de Peters inspirados em Pedagogia do Oprimido, destacarei agora algumas ideias-chave do referido texto. Segundo Peters (1999, p. 158):

\begin{abstract}
Na visão freireana, a linguagem não pode ser dissociada do seu contexto social e político ou do seu papel criador de estratégias de ação. [...] Freire descobriu que existe uma relação íntima entre reflexão e ação [...] para ele a linguagem real sempre envolve a práxis, e usar uma linguagem real significa mudar o mundo. [...] O significado de uma palavra, segundo ele, só pode existir em uma situação concreta, isto é, na relação do indivíduo com o mundo. A base dessa visão é uma teoria semântica específica, a qual define o significado como algo que não é inerente à palavra, possuindo apenas uma existência semântica potencial, que se torna real em um contexto específico.
\end{abstract}

Ao falar do projeto africano, Peters (1999, p. 160) escreve: “Com Paulo Freire, também aprendi que nenhuma mudança fundamental é possível sem desmistificação da realidade.” A partir desse princípio, Peters (1999, p. 166) afirma: "Mitos: seja qual for o formato em que são transmitidos - lendas, provérbios, canções ou textos religiosos - quando legitimam o poder de um homem sobre outro, gerando a exploração e a discriminação sexual, precisam ser submetidos à análise crítica." Em seguida ele elenca uma série de provérbios, canções e histórias populares escancaradamente machistas, que "[...] requerem um processo de desmistificação." E ele declara: "Daí o esforço contínuo dos grupos populares, em meu projeto africano, em desvelar a realidade e criar a utopia, no sentido freireano.” (PETERS, 1999, p. 161). 
Naquele projeto realizado no Congo, Peters afirma enfaticamente que $\mathrm{Pe}$ dagogia do Oprimido pode inspirar, no campo da práxis pedagógico-política, projetos de relevância internacional, na luta para a transformação de tradições culturais e estruturas de poder marcadas por modalidades tremendamente opressivas da mulher. A crítica pela crítica, dissociada do contexto histórico concreto e da dinâmica de uma práxis de transformação, como é o caso de Pedagogia do Oprimido, perde toda credibilidade científica e relevância pedagógico-política.

Uma renomada professora universitária brasileira, Ana Mae Barbosa, enfatiza, no mesmo livro de que participou Peters, como ele o faz, a relação entre a teoria, o contexto histórico-cultural e a práxis da transformação. É o que aparece já no parágrafo inicial do seu texto:
A Pedagogia do Oprimido é filosofia, sociologia, educação e, sobretudo, um tratado de epistemologia. É um livro nascido da luta empreendida por seu autor para dar aos indivíduos de todas as classes sociais o direito de serem sujeitos de seu próprio processo de conhecimento e para despertar, nesses indivíduos, o interesse, a agudeza e a coragem necessários a fim de participarem do processo de transformação de suas sociedades. A consciência da prática gerou a teoria que permeia a Pedago- gia do Oprimido. (BARBOSA, 1999, p. 23, grifo nosso).

Alguns parágrafos adiante lemos um depoimento dos mais surpreendentes da mesma autora:

Fui sujeito da pedagogia em favor do oprimido de todas as classes sociais e de todos os gêneros, praticada por Paulo Freire, e, mais tarde, fui testemunha da influência que essa pedagogia transformada em teoria operou nas universidades americanas, africanas, inglesas e européias em geral. (BARBOSA, 1999, p. 24, grifo nosso).

Três parágrafos depois, ela afirma que “[...] o livro Pedagogia do Oprimido foi a resposta convincente para os movimentos reivindicatórios dos estudantes do mundo desenvolvido [...]" (BARBOSA, 1999, p. 24, grifo nosso).

Das citações feitas destacarei dois aspectos. O primeiro, de que a autora citada interpreta a obra de Freire como "[...] pedagogia em favor do oprimido de todas as classes sociais e de todos os gêneros." Recentemente, nos meios de comunicação houve comentários sobre uma obra que fala de cinco gêneros, não apenas de dois, como no best seller de Simone de Beauvoir. Em segundo lugar, Ana Mae Barbosa, embora como mulher, não sentiu a necessidade de escrever "Em favor do oprimido e da oprimida" e na outra citação, "dos estudantes e das estudantes". O problema de a 
linguagem ser ou não machista não está nesses detalhes. E aqui creio que Peters vai ao âmago do problema, no texto já citado. Ao falar da "linguística feminista" e da importância de usar continuamente o gênero feminino quando se referia às mulheres, justifica: "Assim posso contribuir, em longo prazo, para a realização de mudanças da realidade cultural, social, econômica e política.” Essa perspectiva de mudança em longo prazo encontra uma formulação semelhante em Paulo Freire, que no livro Pedagogia da Esperança escreveu: "A recusa à ideologia machista, que implica necessariamente recriação da linguagem, faz parte do sonho possível em favor da mudança do mundo." (FREIRE, 1992, p. 68).

Na Suíça, um movimento amplo de mulheres buscou na Pedagogia do Oprimido e na visão política do IDAC a inspiração para a luta, relatada no livro Vivendo e aprendendo: Experiências do Idac em educação popular, de autoria do grupo IDAC (OLIVEIRA; HARPER, 1983). No capítulo 3, As Mulheres em Movimento (OLIVEIRA; HARPER,1983, p. 39-68), sobre a $1^{\text {a }}$ assembleia lemos: "Éramos quinhentas a perceber a mesma coisa e, para falar dessa 'coisa' que ninguém sabia muito bem o que era, nos dividimos em grupos. Esses grupos, que proliferaram em Genebra e na Suíça, se constituíam e se desfaziam segundo os interesses das participantes.” (OLIVEIRA; HARPER, 1983, p. 43).

Na pesquisa da realidade, para "[...] escrever sua própria história" (OLIVEIRA; HARPER, 1983, p. 46), “[...] cabia às estudantes da universidade o levantamento do que Freire chamaria o universo temático das habitantes do conjunto residencial” (OLIVEIRA; HARPER, 1983, p. 52). Nessa “[...] reinvenção de sua identidade individual e coletiva", prolongando-se em ação política, o movimento visava um processo amplo de transformação social (OLIVEIRA; HARPER, 1983, p. 67).

Um ano e meio antes de sua morte, no livro À Sombra desta Mangueira Freire (1995, p. 87) denuncia várias vezes todas as formas de discriminação, “[...] não importa se contra o negro, a mulher, o homossexual, o índio, o gordo, o velho." Ele proclama que é um imperativo ético lutar contra a discriminação, e explicita: "Discriminados porque negros, mulheres, homossexuais, trabalhadores, brasileiros, árabes, judeus, não importa por quê, temos o dever de lutar contra a discriminação. A discriminação nos ofende a todos porque fere a substantividade do ser." (FREIRE, 1995a, p. 70).

Voltando ao início desses escritos, lembremos a maneira como Freire começou sua fala na UFRGS, perante um público majoritário de mulheres: "Minhas prezadas professoras." Ele quis criar uma situação de impacto para, em seguida, chamar a atenção para a linguagem "machista". Sem a intenção do impacto, ele poderia ter 
começado, como muitas vezes fazemos: "Prezados professores e prezadas professoras". Ou num tom mais cavalheiresco: "Prezadas professoras e prezados professores". Nem a modalidade gramatical do impacto, nem qualquer uma das outras duas muda a realidade, como não muda se, ao escrevermos, usamos o recurso ortográfico "prezados/as professores/as". O problema é muito mais profundo e radical, desde milênios. Daí que Peters, como grande linguista, comprometido com uma práxis de transformação, tenha escrito, com extrema sabedora: "Assim posso contribuir, em longo prazo para a realização de mudanças da realidade cultural, social, econômica e política." (PETERS, 1999, p. 160, grifo nosso).

Sem essa consciência da realidade e sem o compromisso com a sua transformação, nuanças apenas gráficas, ortográficas, sintáticas ou semânticas, não mudam a realidade, como aconteceu, aliás, com as famosas reformas ortográficas da língua portuguesa. Em minha trajetória de octogenário, lembro-me ao menos de três. Na primeira, creio que na década de 1940, os "poderosos" da língua decretaram que não se escreveria mais "physica", mas sim "física", e que o "k", que todo o mundo continua achando chique usar, não se usaria mais. Na segunda reforma, aboliram o esdrúxulo acento diferencial, decidindo que não se escreveria mais "tôda", nem "êle", mas sim toda e ele, porque ninguém mais confundiria toda com toda, uma pequena árvore, se não me engano, da África, ele com ele (o nome da letra "l"). Na última, eliminaram o trema ("), como em "lingüística", que no livro citado, em 1999, ainda se escrevia "lingüística".

Todas as três reformas foram feitas contra as propostas de grandes linguistas da língua portuguesa, como Câmara Cascudo, que propunham reformas muito mais profundas, que nunca serão feitas, porque com elas todas as brasileiras e todos os brasileiros escreveriam corretamente, sem os horrores infinitos de regras irracionais de ortografia, que tornam o estudo do português odioso para muitos alunos. Darei apenas um exemplo: fazenda, casa e exercício, três grafias diferentes ( $\mathrm{z}, \mathrm{s}$ e x), para o mesmo fonema, a mesmíssima pronúncia. Os "donos" da gramática argumentam que a etimologia latina exige assim. Mas os linguistas (agora sem trema) mais competentes defendem que etimologia não é escrever como os autores latinos escreviam, porque a etimologia também é histórica, como a semântica, acompanhando, por isso, a evolução da língua.

Resumindo a argumentação, não adianta querer mudar, de maneira artificial, burocrática e autoritária a gramática, porque não será somente com essa mudança que se vai mudar a realidade, no caso dos problemas de gênero, a discriminação, a dominação, a opressão da mulher por parte do homem, numa cultura plurimilenar de 
machismo. Nossa luta tem que ser para mudar a realidade opressora. Assim, a língua, com sua gramática anacrônica e autoritária, também mudará. Esta foi a luta de Freire e está sendo de milhões de pessoas no mundo, que não o repetem, como ele nunca quis que fosse, mas o recriam, como ele propôs numa de suas últimas entrevistas: "Cabe a vocês inventar novas pedagogias."

\section{REFERENCIAS}

BARBOSA, A. M. Sobre a Pedagogia do Oprimido. In: FREIRE, A. M. A. (Org.). A Pedagogia da Libertação em Paulo Freire. São Paulo: Ed. Unesp, 1999.

FREIRE, A. M. A. Nita e Paulo: Crônicas de amor. São Paulo: Olho Dágua, 1998.

FREIRE, P. À sombra desta mangueira. São Paulo: Olho Dágua, 1995a.

FREIRE, P. Cartas à Guiné-Bissau: registros de uma experiência em processo. Rio de Janeio: Paz e Terra, 1978.

FREIRE, P. Opressão, classe e gênero. In: FREIRE, A. M. A. (Org.). Pedagogia dos Sonhos Possíveis. São Paulo: Ed. Unesp, 2001.

FREIRE, P. Pedagogia da indignação: cartas pedagógicas e outros escritos. São Paulo: Ed. Unesp, 2000.

FREIRE, P. Pedagogia do oprimido. 46. ed. São Paulo: Paz e Terra, 2007.

FREIRE, P. Pedagogia dos sonhos possíveis. São Paulo: Ed. Unesp, 2001.

FREIRE, P. Pedagogia da esperança. São Paulo: Paz e Terra, 1992.

FREIRE, P. Cartas a Cristina: reflexões sobre minha vida e minha práxis. São Paulo, Unesp. 1994.

FREIRE, P. Professora sim, tia não: cartas a quem ousa ensinar. 6. ed. São Paulo: Olho Dágua, 1995b.

FREIRE, P. Conscientização. Teoria e Prática da libertação: uma introdução ao pensamento de Paulo Freire. São Paulo: Cortez \& Moraes, 1979.FREIRE, P.; SHOR, I. Medo e Ousadia: O cotidiano do professor. Rio de Janeiro: Paz e Terra, 1986.

GADOTTI, M. et al. (Org.). Paulo Freire: Uma biobibliografia. São Paulo: Cortez e Instituto Paulo Freire, 1996. 
MCLAREN, P. et al. (Org.). Paulo Freire: Poder, desejo e memórias de libertação. Porto Alegre: Artmed, 1998.

OLIVEIRA, R. D.; HARPER, B. As Mulheres em Movimento: ler a própria vida, escrever a própria história. In: FREIRE, P. et al. (Org.). Vivendo e Aprendendo: Experiências do Idac em educação popular. 6. ed. São Paulo: Brasiliense, 1983.

PETERS, M. Aspectos semânticos e pragmáticos da pedagogia de Paulo Freire. In: FREIRE, A. M. A. (Org.). A Pedagogia da Libertação em Paulo Freire. São Paulo: Ed. Unesp, 1999.

RICOEUR, P. Histoire et Verité. Paris: Seuil, 1955.

SILVA, M. A. Feminismo. In: STRECK, D. R.; REDIN, E.; ZITKOSKI, J. J. (Org.). Dicionário Paulo Freire. 2. ed. Belo Horizonte: Autêntica, 2010.

TORRES, R. M. Professora sim, tia não. In: GADOTTI, M. et al. (Org.). Paulo Freire: Uma biobibliografia. São Paulo: Cortez e Instituto Paulo Freire, 1996.

VIEZZER, M. L. Paulo Freire e as Relações Sociais de Gênero. In: GADOTTI, M. et al. (Org.). Paulo Freire: Uma biobibliografia. São Paulo: Cortez Editora \& Instituto Paulo Freire, 1996.

WEYH, C. Mudança/Transformação Social. In: STRECK, D. R.; REDIN, E.;

ZITKOSKI, J. J. (Org.). Dicionário Paulo Freire. 2. ed. Belo Horizonte: Autêntica, 2010 .

Recebido em: 16 de maio de 2016

Aceito em: 30 de agosto de 2016

Endereço para contato: Vítor Barreto, 2288, Centro, 92010-000, Canoas, Rio Grande do Sul, Brasil; baldo.andreola@gmail.com 
